Appl Microbiol Biotechnol (1989) 30:283-289

\title{
Electrotransformation of intact and osmotically sensitive cells of Corynebacterium glutamicum
}

\author{
Hendrik Wolf ${ }^{1}$, Alfred Pühler ${ }^{2}$, and Eberhard Neumann ${ }^{1}$ \\ ${ }^{1}$ Fakultät für Chemie, Universität Bielefeld, Postfach 8640, D-4800 Bielefeld 1, Federal Republic of Germany \\ ${ }^{2}$ Fakultät für Biologie, Universität Bielefeld, D-4800 Bielefeld, Federal Republic of Germany
}

Summary. Intact and osmotically sensitive cells of Corynebacterium glutamicum can be efficiently transformed by electroporation. This was shown by using the plasmid vector pUL-330 $(5.2 \mathrm{~kb})$, containing the kanamycin resistance gene of transposon $\operatorname{Tn} 5$. The following electric parameters yielded efficient transformation. For intact cells: one exponentially decaying field pulse $E=E_{0} \exp \left(-t / \tau_{E}\right)$ with time constants $\tau_{E}=450$ $500 \mu$ s and with initial field intensities of $E_{0}=35$ $40 \mathrm{kV} \mathrm{cm}{ }^{-1}$; prepulse temperature $20^{\circ} \mathrm{C}$. Cell regeneration (survival) was $100 \%-80 \%$. Transformation efficiency can be increased by an additional freeze and thaw cycle of the cells, prior to electroporation. Lysozyme treated cells (osmotically sensitive) were transformed with three successive pulses of $E_{0}=25-30 \mathrm{kV} \mathrm{cm}^{-1}$. Cell regeneration under these conditions was found to be $20-30 \%$. The optimum yield of transformants/ $\mu$ g plasmidDNA was $3 \times 10^{3}$ for intact cells, $2 \times 10^{4}$ for intact cells which were frozen and thawed twice and $7 \times 10^{4}$ for osmotically sensitive cells if the cell suspension was pulsed at a cell density of 1 $3 \times 10^{8} / \mathrm{ml}$ and at a DNA concentration of $0.2 \mu \mathrm{g} /$ $\mathrm{ml} \mathrm{up} \mathrm{to} \leq 2 \mu \mathrm{g} / \mathrm{ml}$. The data obtained for osmotically sensitive cells suggest that the temperature increase accompanying the electric field pulse enhances colony formation and transformation efficiency if the initial prepulse temperature is $\geq 20^{\circ} \mathrm{C}$, although regeneration of electroporated C. glutamicum cells starts to decrease at temperatures $\geq 20^{\circ} \mathrm{C}$.

\section{Introduction}

Corynebacterium glutamicum is a nonpathogenic soil microorganism which is widely used in the in-

Offprint requests to: E. Neumann dustrial production of amino acids (Martin et al. 1987). For genetic and biotechnological purposes these bacteria have been transformed by the polyethylene glycol (PEG) method with different plasmid vectors (Yoshihama et al. 1985).

Recently the electroporation technique has been introduced to efficiently transform cells in a simple manner (Neumann et al. 1982). This technique is based on the observation that electric pulses of high field intensity and short duration cause transient permeability changes in cell membranes (Neumann and Rosenheck 1972, 1973). Meanwhile there are numerous reports on the electrotransformation of animal and plant cells. Electroporation is also applied to the transformation of bacterial microorganisms. First example was the stimulation of transformation of Bacillus cereus protoplasts by electric field pulses (Shivarova et al. 1983); more recently the electroporation technique was successfully applied to transform Streptococcus thermophilus (Somkuti and Steinberg 1987), Streptomyces lividans protoplast (Mac Neil 1987), Lactobacillus casei (Chassy and Flickinger 1987), Campylobacter jejuni (Miller et al. 1988), different strains of Lactic streptococci (Powell et al. 1988) Enterococcus faecalis protoplasts, Pseudomonas putida and Escherichia coli (Fiedler and Wirth; Taketo 1988). Although Corynebacteria osmotically sensitive cells can be transformed by the PEG technique, there is actually no method available to transform intact cells.

In this study we report the transformation of intact and osmotically sensitive $C$. glutamicum cells by high voltage-electroporation (up to $40 \mathrm{kV}$ $\mathrm{cm}^{-1}$ ). The influence of the variation of electrical parameters on transformation efficiencies of intact cells is described and compared with the transformation of lysozyme treated (osmotically sensitive) cells. Because the application of high voltage field pulses is physically limited by tem- 
perature and pressure effects, most parameters influencing transformation were performed with osmotically sensitive cells which can be transformed without technical problems.

\section{Materials and methods}

The transformation experiments were performed with Corynebacterium glutamicum (ATCC 13032). As a vector the pUL330 -plasmid with a length of $5.2 \mathrm{~kb}$ isolated from Corynebacterium glutamicum was used. It contains the kanamycin resistance gene of transposon $\operatorname{Tn} 5$ (Santamaria et al. 1985).

DNA isolation and manipulation. Large scale isolation of plasmid DNA was performed according to Birnboim and Doly (1979), rapid screening of plasmid DNA contents of transformed cells according to Santamaria et al. (1985). For electrotransformation plasmids purified by cesiumchloride ethidiumbromide density gradient centrifugation were used. DNA concentration was determined spectrophotometrically. One optical density unit at $\lambda=260 \mathrm{~nm}$ corresponds to $50 \mu \mathrm{g} \mathrm{ml}^{-1}$ (see Thierbach et al. 1988). Plasmid DNA and fragments cleaved by restriction enzymes were analysed by agarose gel electrophoresis according to Maniatis et al. (1982).

Preparation of osmotically sensitive cells by lysozyme treatment. Osmotically sensitive cells, retaining the original rod shape, were prepared in a growth medium containing $0.5 \%$ glycine (Thierbach et al. 1988), except that the cells were incubated in buffer with $2.5 \mathrm{mg} \mathrm{ml}^{-1}$ lysozyme and shaked for $3.5 \mathrm{~h}$ at $30^{\circ} \mathrm{C}$.

Electrotransformation of cells. Frozen intact and osmotically sensitive cells were thawed, spun down in a Heraeus biofuge for $5 \mathrm{~min}$ at $6000 \mathrm{rpm}$, washed with electroporation medium (272 $\mathrm{mM}$ sucrose, $10 \mathrm{mM}$ HEPES, $1 \mathrm{mM} \mathrm{MgCl}_{2}$, adjusted with $\mathrm{KOH}$ to $\mathrm{pH}$ 7.4), resuspended carefully and kept on ice. Cells were mixed with DNA and filled into the electroporation chamber. After application of a single or of several successive pulses the cells were diluted threefold in Tris/succinate/Mg/ $\mathrm{Ca}$ (TSMC) medium supplemented with $0.1 \%$ yeast, $0.1 \%$ casaminoacids and $0.1 \%$ glucose as described by Thierbach et al. (1988). After incubation for $1 \mathrm{~h}-3 \mathrm{~h}$ at $30^{\circ} \mathrm{C}$ cells were plated on regeneration medium ( $1 \%$ Agar, $1 \%$ tryptone, $0.5 \%$ yeast, $1 \% \mathrm{NaCl}, 500 \mathrm{mM}$ sorbitol, $20 \mathrm{mM} \mathrm{MgCl}, 20 \mathrm{mM} \mathrm{CaCl}$ ) with $17.5 \mu \mathrm{g}$ kanamycin $/ \mathrm{ml}$ to select for transformed cells. Clones developing under these conditions after 2-3 days were transfered to PA-medium containing $25 \mu \mathrm{g}$ kanamycin/ml. Dilutions in TSMC-medium were plated on regeneration medium without antibiotic to determine the number of cells which survive the field pulse treatment. As a control the same procedure was performed with an unpulsed sample. The cell density for the electroporation experiments was in the range of $0.9-4 \times 10^{8} / \mathrm{ml}$. DNA concentration was $0.2-2 \mu \mathrm{g} / \mathrm{ml}$.

Electroporation conditions. Because of the small cell size a high voltage generator (designed by C. R. Rabl; DIA-RT of Fa. Dialog, Düsseldorf) was used in combination with high-voltage capacitors of the capacitances $C=10,21$ and $50 \mathrm{nF}$. The apparatus produces exponentially decaying electric pulses $U=U_{0} \exp \left(-t / \tau_{E}\right)$; the initial voltage $U_{0}$ is adjustable to up to $U_{0}=40 \mathrm{kV}$. The pulse length is given by the exponential decay time constant $\tau_{E}=R \cdot C, R$ is the resistance (reciprocal of the conductance) of the solution and $C$ is the capacitance of the discharge circuit (determined by the high voltage capacitor). The electric conductance of the HEPES-buffered sucrose electroporation medium measured in the electroporation chamber is $G=1 / R=100 \mu \mathrm{S}$ at $20^{\circ} \mathrm{C}$. Thus the time constants of the applied pulses were adjustable up to $500 \mu \mathrm{s}$. The electroporation chamber was of cylindrical shape (Neumann et al. 1982). The top and bottom stainless steel electrodes had an interelectrode distance of $1 \mathrm{~cm}$. The chambers were sterilized with $70 \%$ ethanol, dried and then filled with $400 \mu 1$ cell suspension. The effective volume which is within the homogenous electric field of the electrodes is $322 \mu \mathrm{l}$. At higher field strengths $\left(E_{0}>30 \mathrm{kV}\right.$ $\left.\mathrm{cm}^{-1}\right)$ and larger pulse durations $\left(\tau_{E}>300 \mu \mathrm{s}\right)$ the method however has physical limits; temperature and pressure effects finally cause partial expulsion of the solution from the sample chamber.

\section{Results and discussion}

\section{Electrosensitivity of C. glutamicum}

Cell suspensions of osmotically sensitive $C$. glutamicum cells were exposed to varying field intensities, pulse durations and pulse numbers. Because of the small cell size strong electric fields are required to electroporate the cells. As expected the electric field dependence of cell regeneration is different for short ( $0.4 \mathrm{~ms})$ and for long $(10 \mathrm{~ms})$ duration pulses; see Fig. 1. At pulse lengths of $\tau_{E}=0.35-0.4 \mathrm{~ms}$ the initial field intensity, at which $50 \%$ cell regeneration occurs, is $E_{0}=25-30 \mathrm{kV} \mathrm{cm}^{-1}$. At $\tau_{E}=10 \mathrm{~ms}, E_{0}$ of $50 \%$ cell regeneration is $5.5 \mathrm{kV} \mathrm{cm}{ }^{-1}$. There are only slight differences in cell regeneration for pulses of 250 and $500 \mu$ s (data not shown). Intact cells show greater resistance to the electric fields applied.

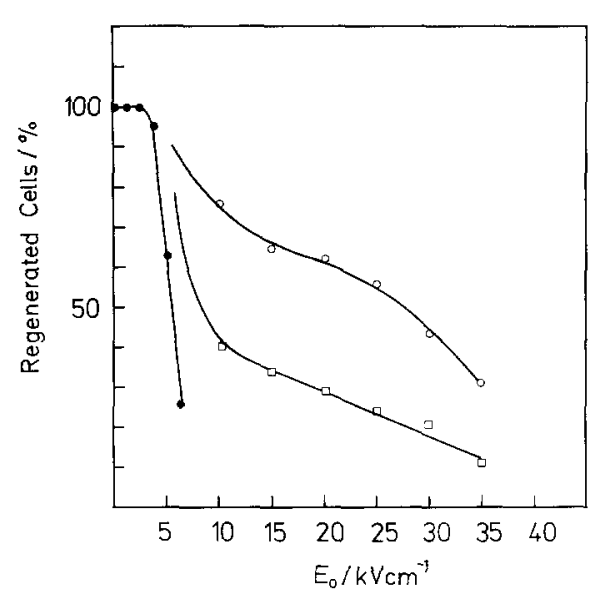

Fig. 1. Electrosensitivity of C. glutamicum osmotically sensitive cells at long pulse durations $\left(\tau_{E}=10 \mathrm{~ms}\right)$, cell density $5 \times 10^{8} / \mathrm{ml}$, prepulse temperature $20^{\circ} \mathrm{C},(-)$, and at short pulse durations $\left(\tau_{E}=360-380 \mu \mathrm{s}\right)$, prepulse temperature $4^{\circ} \mathrm{C}$, cell density $10^{8} / \mathrm{ml}$ for a single exponential pulse $(O)$ and for three successive pulses $(\square)$ at intervals of $5 \mathrm{~s}$ as a function of the initial field strength $E_{0}$ 
Regeneration of cells starts to decrease at $E_{0}=35$ $\mathrm{kV} \mathrm{cm}{ }^{-1}$ for cells thawed once and at $E_{0}=30 \mathrm{kV}$ $\mathrm{cm}^{-1}$ with an additional freeze and thaw cycle. At $\tau_{E}=450 \mu \mathrm{s}$ about $80 \%$ of the cells survive. No change in cell morphology of intact and osmotically sensitive cells was observed after pulse application in the phase contrast microscope.

\section{Field strength dependence of the transformation efficiency (TE)}

Since the yield of transformed cells depends on cell density and DNA content, the transformation efficiency (TE) is defined for a given cell number per $\mathrm{ml}$ and the $\mu \mathrm{g}$ amount of DNA per $\mathrm{ml}$ suspension as

$\mathrm{TE}=\frac{\text { number of transformants } / \mathrm{ml}}{1 \mu \mathrm{g} \mathrm{DNA} / \mathrm{ml}}$

As seen in Fig. 2 the transformation efficiencies for $\tau_{E}=450 \mu \mathrm{s}$ with intact cells and $400 \mu \mathrm{s}$ with osmotically sensitive cells increase with increasing initial field strength. The maximum value of $\mathrm{TE}$ for one pulse lies between 35 and $40 \mathrm{kV} \mathrm{cm}^{-1}$ for intact cells and 25 and $30 \mathrm{kV} \mathrm{cm}^{-1}$ for osmotically sensitive cells. The survival of osmotically
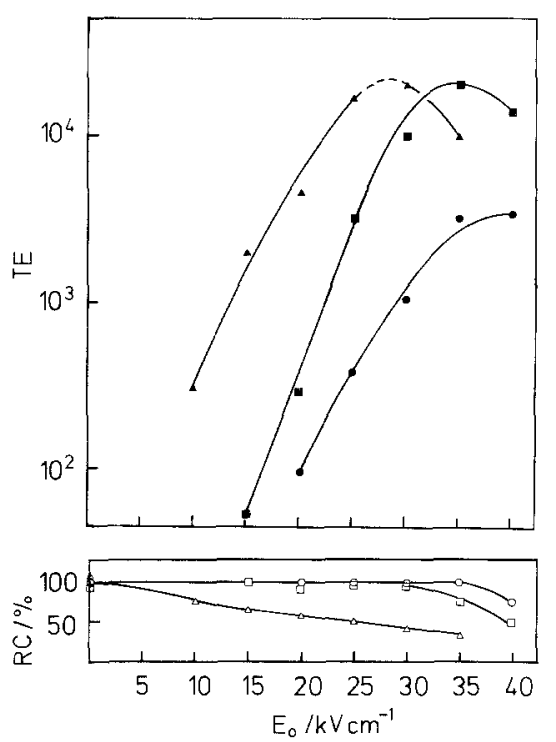

Fig. 2. Transformation efficiency (TE, full symbols) and regenerated cells (RC, open symbols) of intact cells after one $(\bullet, 0)$, after a second freezing-thawing cycle $(\boldsymbol{\square}, \square)$ and of osmotically sensitive cells $(\boldsymbol{\Delta}, \Delta)$. Electroporation conditions: single pulse of $\tau_{E}=450 \mu \mathrm{s}$ for intact and $\tau_{E}=385 \mu \mathrm{s}$ for osmotically sensitive cells as a function of the field strength $E_{0}$. Cell density $1.0-1.3 \times 10^{8}$ cells $/ \mathrm{ml} ; 0.2 \mu \mathrm{g} \mathrm{DNA} / \mathrm{ml}$; prepulse temperature $20^{\circ} \mathrm{C}$ sensitive cells at this field intensity range is about $50 \%$ and TE $\geq 2 \times 10^{4}$. TE of intact cells is $3 \times 10^{3}$ and increases to $2 \times 10^{4}$ after an additional freeze and thaw cycle. Thus, repeated freezing and thawing apparently changes the cell wall to a certain extent and facilitates uptake of DNA comparable to lysozyme treated cells. The transformation efficiencies of intact cells after two freeze-thawing cycles and of osmotically sensitive cells reach similar values, but the electrosensitivity of osmotically sensitive cells is much higher compared with the intact cells.

\section{Effect of the pulse length on TE}

Experiments with capacitors of different capacitances $(C=10,21$ and $50 \mathrm{nF})$ indicate that the number of transformants/ $\mu \mathrm{g}$ DNA increases with increasing pulse duration (see Fig. 3). The lysozyme treated cells are more efficiently transformed than the intact cells. Transformants of osmotically sensitive cells appear at pulse durations $\tau_{E}<100 \mu \mathrm{s}$ at an initial field strength $E_{0}=25 \mathrm{kV}$ $\mathrm{cm}^{-1}$. The pulse duration limit for transformation of intact cells is $\tau_{E}>100 \mu \mathrm{s}$ at $E_{0}=35 \mathrm{kV} \mathrm{cm}^{-1}$.
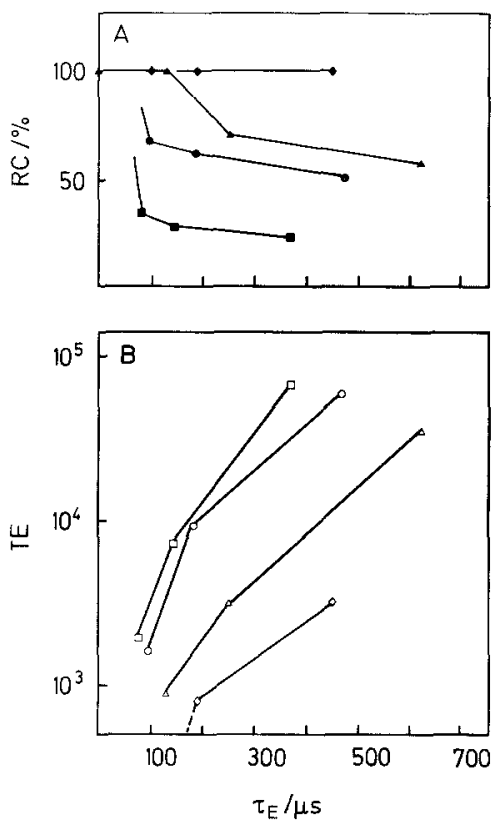

Fig. 3. Cell regeneration (A) and electrotransformation efficiency (B) of intact and osmotically sensitive cells as a function of the pulse length $\tau_{E}$. Intact cells were treated with a single pulse of $E_{0}=35 \mathrm{kV} \mathrm{cm}{ }^{-1}$ at $T=20^{\circ} \mathrm{C}$, cell density $1.7 \times 10^{8} / \mathrm{ml}(\diamond, \diamond)$. Osmotically sensitive cells were incubated before the pulse at $T=0^{\circ} \mathrm{C}(\Delta, \triangle), 20^{\circ} \mathrm{C}(\bullet, O)$ and $30^{\circ} \mathrm{C}(\square, \square) ; E_{0}=25 \mathrm{kV} \mathrm{cm}^{-1}$, single pulse. Incubation time at the various temperatures before pulsing was $15 \mathrm{~min}$. Cell density was $2.5 \times 10^{8} / \mathrm{ml}$; DNA concentration was $0.2 \mu \mathrm{g} / \mathrm{ml}$ 
Table 1. Effect of the number of pulses on the transformation efficiency (TE) and regeneration of intact (IC) and osmotically sensitive (OSC) C. glutamicum cells at pulse interval times of $5 \mathrm{~s}$ and $2 \mathrm{~min}$

\begin{tabular}{llllll}
\hline $\begin{array}{l}\text { No. } \\
\text { of pulses }\end{array}$ & \multicolumn{5}{l}{ Transformation efficiency (TE) $\times 10^{3}$} \\
\cline { 2 - 6 } & 1 & 2 & 3 & 4 & 10 \\
\hline IC, $(5 \mathrm{~s})$ & 3.2 & 0.29 & 0 & n.d. & n.d. \\
IC, $(2 \mathrm{~min})$ & 3.2 & 2.6 & n.d. & 1.2 & 0 \\
OSC, $(5 \mathrm{~s})$ & 8.0 & 16 & 21 & 5.6 & n.d. \\
\hline \multicolumn{7}{l}{} & \multicolumn{7}{l}{ Regenerated cells $/ \mathrm{ml} \times 10^{8}$} & & \\
\hline IC, $(5 \mathrm{~s})$ & 1.1 & 0.51 & 0.17 & n.d. & n.d. \\
IC, $(2 \mathrm{~min})$ & 1.1 & 0.67 & n.d. & 0.39 & 0.06 \\
OSC, $(5 \mathrm{~s})$ & 0.37 & 0.19 & 0.16 & 0.15 & n.d. \\
\hline
\end{tabular}

$10^{8}$ cells $/ \mathrm{ml}$ were transformed with $0.2 \mu \mathrm{g} \mathrm{DNA} / \mathrm{ml}$. The pulse duration was $\tau_{E}=370 \mu \mathrm{s}$ (OSC) and $450 \mu \mathrm{s}$ (IC). The intact cells were frozen and thawed once. The time intervals between the pulses are given in brackets

\section{Effect of the number of pulses on TE}

As shown in Table 1, TE of osmotically sensitive cells can be increased by a factor of 2.5 with three successive pulses at intervals of $5 \mathrm{~s}$ compared with TE of a single pulse. TE of intact cells decreases with successive pulses of $5 \mathrm{~s}$ and 2 min intervals. At 10 pulses with 2 min intervals no transformants were observed on selection plates; cell regeneration decreased to $6 \%$. At the conditions $E_{0}=25 \mathrm{kV}$ $\mathrm{cm}^{-1}, \tau_{E}=300 \mu$ s and at the prepulse temperature of $20^{\circ} \mathrm{C}$, the temperature of the cell suspension increases by $\approx 12^{\circ} \mathrm{C}$ per pulse. The temperature after four successive pulses rises transiently up to $\approx 45^{\circ} \mathrm{C}$; see Figure $6 \mathrm{~B}$. Thus the electroporation procedure at these conditions involves an electrical and a thermal effect.

\section{$D N A$ concentration and transformation efficiency}

Figure 4 shows that the number of transformants from osmotically sensitive cells increases linearly with DNA concentration $\left(E_{0}=25 \mathrm{kV} \mathrm{cm}^{-1}\right.$ and $\left.\tau_{E}=500 \mu \mathrm{s}\right)$. The transformation efficiency, however, remains approximately constant up to DNA concentrations of $2 \mu \mathrm{g} / \mathrm{ml}$, followed by a decrease at higher DNA concentrations. Therefore, for efficiency reasons, the DNA concentration for electroporation of $C$. glutamicum osmotically sensitive cells should not exceed $2 \mu \mathrm{g} / \mathrm{ml}$. Note that at $2 \mu \mathrm{g} \mathrm{DNA} / \mathrm{ml}$ and $10^{8}$ cells $/ \mathrm{ml}$ the ratio of plasmid molecules to cells is $\approx 3500: 1$.

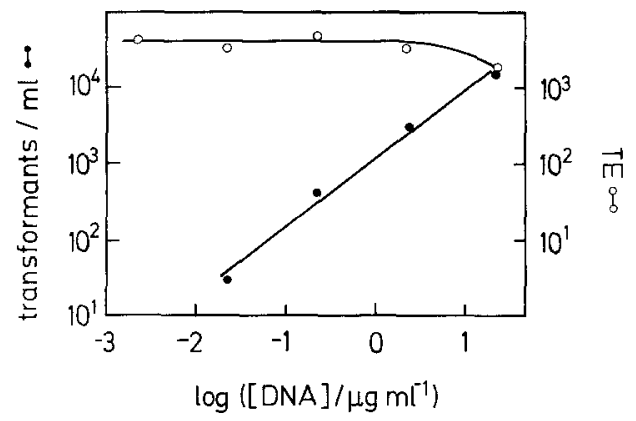

Fig. 4. The number of transformants/ml ( , left scale) and the transformation efficiency $(O$, right scale), respectively, as a function of DNA concentration (logarithmic scale). Aliquots of a cell suspension of $9 \times 10^{7} / \mathrm{ml}$ were treated with a single pulse, $E_{0}=25 \mathrm{kV} \mathrm{cm}{ }^{-1}, \tau_{E}=500 \mu \mathrm{s}$ at the prepulse temperature $4^{\circ} \mathrm{C}$

\section{Cell number and transformation efficiency}

In the cell density range of $10^{7}-10^{9} / \mathrm{ml}$, TE for osmotically sensitive cells increases linearly from $5 \times 10^{3}$ (at $10^{7} \mathrm{OSC} / \mathrm{ml}$ ) to $2 \times 10^{5}$ (at $10^{9} \mathrm{OSC} /$ $\mathrm{ml}$ ) at a DNA concentration of $0.2 \mu \mathrm{g} / \mathrm{ml} ; E_{0}=25$ $\mathrm{kV} \mathrm{cm}{ }^{-1}, \tau_{E}=400 \mu \mathrm{s}$, single pulse, prepulse temperature $20^{\circ} \mathrm{C}$. At higher cell densities TE starts to decrease (data not shown).

\section{Effect of addition of PEG to the electroporation medium}

Transformation of Bacillus cereus protoplasts have been stimulated by electric field pulses using an electroporation buffer which contained $40 \%$ (w/w) PEG (Shivarova et al. 1983). Shillito et al. (1985) described an increase in the transformation efficiency of tobacco protoplasts in the presence of up to $13 \%$ PEG in the electroporation buffer; the authors state that PEG plays a role in the association of the DNA with the membrane. In order to clarify the role of PEG on the DNA uptake by $C$. glutamicum osmotically sensitive cells electrotransformation experiments were performed with various concentrations of PEG $\left(M_{r}=6000\right)$ in the electroporation buffer (see Fig. 5). In the concentration range up to $30 \%(\mathrm{w} / \mathrm{w})$ the transformation efficiency decreases, indicating that, here, the presence of PEG inhibits cell transformation rather than promoting it. Although the time constant of the pulse increases with higher PEG concentrations because of a decrease of the conductance (by the increased viscosity) of the electroporation buffer, cell survival remains constant. The decrease of the transformation efficiency is there- 

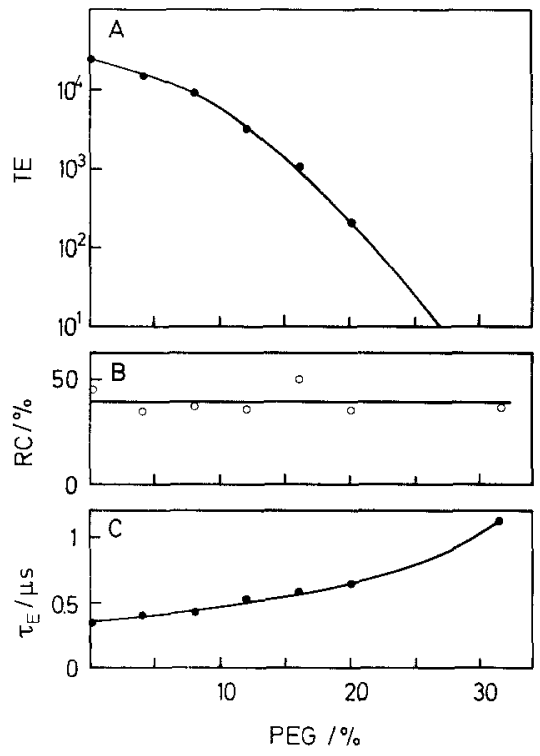

Fig. 5. Transformation efficiency (A, $\bullet$ ), cell regeneration (B, $\mathrm{O})$ and pulse duration $(\mathbf{C}, \boldsymbol{O})$ as a function of increasing PEG-concentrations (weight \%) in the electroporation medium (10 min incubation time). Cells were treated by three successive pulses of $E_{0}=25 \mathrm{kV} \mathrm{cm}-1$ with $5 \mathrm{~s}$ intervals; prepulse temperature $20^{\circ} \mathrm{C}$. Cell density was $1 \times 10^{7} / \mathrm{ml}$ and DNA concentration $0.2 \mu \mathrm{g} / \mathrm{ml}$ )

fore not due to cell death, caused by the longer duration of the pulse. Therefore PEG has no additional cytotoxic effect during the field pulse treatment. When cells are treated with PEG (without electric pulses) in the same low ionic strength buffer as required for long electroporation pulses, the TE increases with enhanced PEG concentration up to a maximum $\left(\approx 0.5 \times 10^{3}\right.$ tranformants/ $\mu \mathrm{g}$ DNA at 20\% PEG and then decreases (data not shown). Transformation efficiency may be low in comparison to optimized protocols because of the lack of $\mathrm{Ca}^{2+}$ ions, which are considered to be essential for optimal action of PEG at the membrane surface. At 20\% PEG the TE of electroporated samples diminished to the same low value (see Fig. 5). In summary, at the low ionic strength buffer conditions the efficiency of transformation of pulsed samples without any PEG was always higher than that of PEG treated samples without applying electric field pulses.

\section{Temperature dependence of cell regeneration}

In Fig. $3 \mathrm{~A}$ it is shown that at a given temperature cell survival decreases with pulse length. At a given pulse length, cell regeneration decreases with increasing temperature. The prepulse temperature was not elevated beyond $30^{\circ} \mathrm{C}$ to avoid
Table 2. Influence of short term (20 s) and long term (5 min) temperature shifts on cell regeneration

\begin{tabular}{rll}
\hline$T\left({ }^{\circ} \mathrm{C}\right)$ & \multicolumn{2}{l}{ Regenerated cells $/ \mathrm{ml} \times 10^{8}$} \\
\cline { 2 - 3 } & $20 \mathrm{~s}$ & $5 \mathrm{~min}$ \\
\hline 0 & 3.5 & 13 \\
20 & 3.8 & 20.0 \\
30 & 3.9 & 11.0 \\
40 & n.d. & 2.0 \\
42 & 2.6 & 1.8 \\
45 & 3.0 & 0.28 \\
48 & 3.0 & 0.01 \\
50 & 2.0 & 0 \\
60 & 1.5 & 0
\end{tabular}

Cells were filled into a microcapillary $(100 \mu \mathrm{l})$ and incubated for $20 \mathrm{~s}$ at the temperature $(T)$ indicated in a water bath and then shifted for $20 \mathrm{~s}$ to $0^{\circ} \mathrm{C}$. For the 5 min incubation time cells were pipetted into an Eppendorf tube

eventual heat shock contributions. In order to maintain comparable ionic strength conditions of the electroporation medium the pulse length is limited by the available high voltage capacitors.

In order to explore the influence of the transient temperature increase after the field pulse, cells in a microcapillary were incubated in a water bath at different elevated temperatures for $20 \mathrm{~s}$ and then transferred to an ice bath for the same time. Regeneration starts to decrease at incubation temperatures $>30^{\circ} \mathrm{C}$. At $42^{\circ} \mathrm{C}$ about $80 \%$ of the initial cell number regenerated and about $50 \%$ at $50^{\circ} \mathrm{C}$. The same experiment with cells in an Eppendorf tube and an incubation time of $5 \mathrm{~min}$ resulted in about $13 \%$ regeneration at $42^{\circ} \mathrm{C}$ and $<1 \%$ at $50^{\circ} \mathrm{C}$ (see Table 2). Therefore the transient temperature increase of a single field pulse does apparently not affect cell regeneration. The transient temperature increase due to multiple pulses with short intervals $(5 \mathrm{~s})$ may contribute to the field induced decrease of cell regeneration (see Fig. 6 B).

\section{Temperature dependence of $T E$}

Figure $3 \mathrm{~B}$ shows that the TE of osmotically sensitive cells increases with increasing pulse length, but differently at different temperatures. In the temperature range explored, the TE at $30^{\circ} \mathrm{C}$ prepulse temperature is the highest one: $\mathrm{TE}=6.8 \times 10^{4}$ transformants $/ \mu \mathrm{g}$ DNA at $E_{0}=25$ $\mathrm{kV} / \mathrm{cm}$ and $\tau_{E}=365 \mu \mathrm{s}$. Due to technical limitations the optimum temperature and pulse length could not yet be determined. If the number of electrotransformed cells is related to the actually 

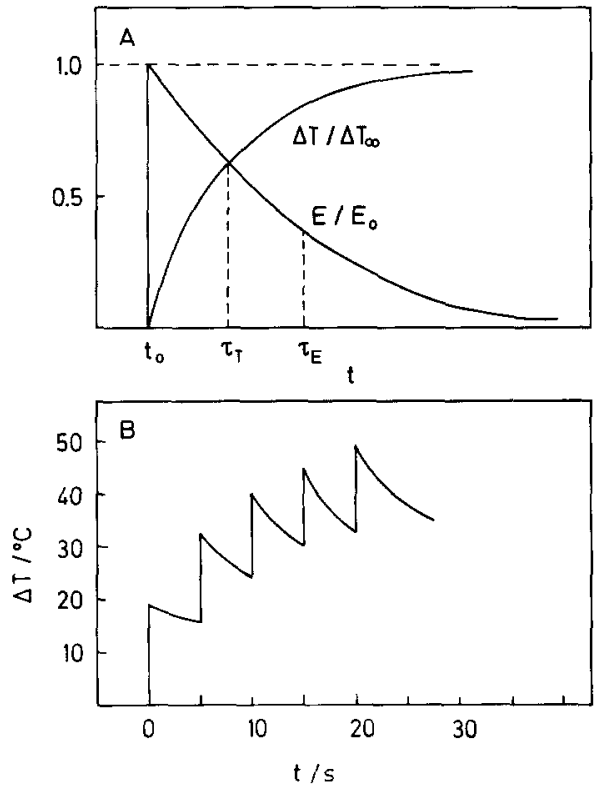

Fig. 6. A: The relative temperature increase $\Delta T /$ $\Delta T_{\infty}=1-\exp \left[-t / \tau_{T}\right]$ accompanying an exponentially decaying electric field pulse, $E=E_{0} \cdot \exp \left[-t / \tau_{E}\right]$, where $\tau_{E}=R \cdot C$ and $\tau_{T}=0.5 \tau_{E}$ as a function of time. $E_{0}$ is the initial field strength at $t_{0}$ and $\Delta T_{\infty}$ is the stationary value at $t \rightarrow \infty$. See text. B: Temperature $(T)$ rise after 5 successive pulses $E_{0}=25 \mathrm{kV}$ $\mathrm{cm}^{-1}$ with $5 \mathrm{~s}$ interval as a function of time. The temperature change is calculated from the calibrated absorbance change of a phenol red solution in TRIS buffer

regenerating cells, it is found that at $30^{\circ} \mathrm{C}$ the ratio of transformed to regenerated cells is as high as $10^{-3}$. It is known that the life time of membrane electroporation strongly decreases at higher temperatures; see e.g. (Jacob et al. 1981; Teissie and Rols 1986). In our case transformation yield increases with increasing prepulse temperature. The primary uptake of DNA is known to be an after-field process probably occuring in the annealing phase of the electroporation cycle (Neumann et al. 1982). Therefore, the electroporative DNA uptake by Corynebacterium glutamicum is apparently not impeded by the presumed faster resealing of the electropores and electrocracks (Sugar et al. 1987).

The application of high voltages at larger pulse durations leads to temperature changes which are no longer negligible. In most of the reports dealing with electroporation of bacteria incubation of the cells at low temperatures (keeping the cells on ice before and after the pulse) is described as favorable for transformation. The pulse energies dissipated into the solution may lead to drastic temperature shifts, depending on the electroporation setup. At capacitances of $25-50 \mu \mathrm{F}$ and voltages of $2.5 \mathrm{kV}$ the transient temperature increase is in a range of $20^{\circ} \mathrm{C}$ (Powell et al. 1988) and $45^{\circ} \mathrm{C}$ (Miller et al. 1988) for a single pulse. Thus cell electroporation at $20^{\circ} \mathrm{C}$ causes transient temperature shifts of $40^{\circ} \mathrm{C}$ to $65^{\circ} \mathrm{C}$ for one pulse. The temperature increase accumulates if multiple pulses with short intervals are applied starting from a prepulse temperature of $4^{\circ} \mathrm{C}$. The large temperature elevations may be unfavorable for cell regeneration and transformation. Figure $6 \mathrm{~A}$ shows the time $(t)$ courses of the field intensity $(E)$, or applied voltage $(U)$, in comparison with the accompanying temperature increase $(\Delta T)$. The relative field strength is given by (Eigen and DeMaeyer 1963; Neumann and Rosenheck 1972):

$E(t) / E_{0}=U(t) / U_{0}=\exp \left(-t / \tau_{E}\right)$

where $U_{0}$ and $E_{0}=U_{0} / d$ are the initial values of the voltage and the field strength at $t=t_{0}=0 ; d$ is the electrode distance. The time constants is $\tau_{E}=R \cdot C$. It is readily shown that the relative temperature change is

$\Delta T(t) / \Delta T_{\infty}=1-\exp \left[-t / \tau_{T}\right]$

where $\tau_{T}=0.5 \tau_{E}$. The final stationary value $\Delta T_{\infty}$ (at $t \rightarrow \infty$ ) can be calculated from the electric pulse energy $\left(0.5 \mathrm{CU}_{0}^{2}\right)$ dissipated as Joule heat. The result is (Eigen and DeMaeyer 1963):

$\Delta T_{\infty}=0.5 \mathrm{CU}_{0}^{2} /\left(\rho c_{P} v\right)$,

where $\rho$ is the density of the solution $\left(\rho \approx 1 \mathrm{~g} \mathrm{~cm}^{-3}\right), \quad c_{P}$ the specific heat $\left(c_{P} \approx 4.18 \mathrm{Jg}^{-1} \mathrm{~K}^{-1}\right)$ and $v$ the sample volume $\left(v=0.32 \mathrm{~cm}^{3}\right)$ between the electrodes. The optimum values of the electrical parameters of C. glutamicum electrotransformations are: $U_{0}=25 \mathrm{kV}$ ( $\left.d=1 \mathrm{~cm}, E_{0}=25 \mathrm{kV} \mathrm{cm}^{-1}\right), C=50 \mathrm{nF}$. Using eq. (4), we obtain $\Delta T_{\infty} \approx 12^{\circ} \mathrm{C}$. Since the electroporation chamber is thermostated, the temperature increase is transient only. Nevertheless several successive pulses lead to a progressive increase in $T$ as demonstrated in Fig. 6 B.

The electroporation data suggest that the temperature increase accompanying the electric pulse enhances the transformation efficiency of Corynebacterium glutamicum.

\section{Conclusion}

The results presented in this report show that intact Corynebacterium glutamicum cells can be transformed by electroporation. Compared to os- 
motically sensitive cells higher electric field parameters have to be applied. The transformation efficiency (TE) of C. glutamicum by chemical agents as PEG is very high for protoplasts $\left(\mathrm{TE}=10^{5}-10^{6}\right)$ and lower for osmotically sensitive cells $\left(\mathrm{TE}=10^{3}-10^{4}\right)$, (Thierbach et al. 1988). With high-voltage electroporation TE is $10^{3}$ for intact cells compared with $10^{5}$ for osmotically sensitive cells. DNA uptake seems to be hindered by the cell wall of the intact cells and of cells with partially removed wall. Since transformants are obtained by application of higher field strengths, strong electric fields probably rearrange the membrane structure in such a way that DNA uptake through membraneous electropores and electrocracks is no longer hindered by the cell wall barrier. It should be possible to find suitable electroporation parameters in order to transform a large variety of bacteria without pretreatment by cell wall removing agents. The temperature increase due to Joule heating at high voltages may turn out to be important for the transformation of bacteria by electroporation.

Acknowledgements. We gratefully acknowledge the help of C. R. Rab1, C. Drewes, R. von Piechowski, T. Matzke, A. Tiemann and V. Selig, the discussions with J. Teissie, Toulouse, and the financial support by the Deutsche Forschungsgemein schaft, grant DFG Ne 227/4 to E. N., and by the French-German Procope Program, grant 311-pro to E. N.

\section{References}

Birnboim HC, Doly J (1979) A rapid alkaline extraction procedure for screening recombinant plasmid DNA. Nucleic Acids Res 7:1513-1523

Chassy BM, Flickinger JL (1987) Transformation of Lactobacillus casei by electroporation. FEMS Microbiol Lett 44:172-177

Eigen M, DeMaeyer L (1963) Relaxation Methods. In: Friess SL, Lewis ES, Weissberger A (eds) Techniques of Organic Chemistry, Vol. 8, Pt. 2, John Wiley, New York, pp 895 1054

Fiedler S, Wirth R (1988) Transformation of Bacteria with Plasmid DNA by Electroporation. Analyt Biochem 170:38-44

Jacob HE, Förster W, Berg H (1981) Microbiological implications of electric field effects, II. Inactivation of yeast cells and repair of their cell envelope. Z Allg Mikrobiologie $21: 225-233$
Mac Neil DJ (1987) Introduction of plasmid DNA into Streptomyces lividans by electroporation. FEMS Microbiol Lett 42:239-244

Maniatis T, Fritsch EF, Sambrook J (1982) Molecular cloning: Laboratory manual. Cold Spring Harbour

Martin JF, Santamaria R, Sandoval H, Del Real G, Mateos LM, Gil JA, Aguilar A (1987) Cloning systems in amino acid-producing Corynebacteria. Biotechnol 5:137-146

Miller JF, Dower WJ, Tompkins LS (1988) High-voltage electroporation of bacteria: Genetic transformation of Campy lobacter jejuni with plasmid DNA. Proc Natl Acad Sci USA 85:856-860

Neumann E, Rosenheck K (1972) Permeability changes induced by electric impulses in vesicular membranes. J Membrane Biol 10:279-290

Neumann E, Rosenheck K (1973) Potential difference across vesicular membranes. J Membrane Biol 14:194-196

Neumann E, Schaefer-Ridder M, Wang Y, Hofschneider PH (1982) Gene transfer into mouse lyoma cells by electroporation in high electric fields. EMBO J 1:841-845

Powell IB, Achen MG, Hillier AJ, Davidson BE (1988) A simple and rapid method for genetic transformation of lactic Streptococci by electroporation. Appl Environ Microbiol $54: 655-660$

Santamaria R, Gil JA, Martin JF (1985) High-frequency transformation of Brevibacterium lactofermentum protoplasts by plasmid DNA. J Bacteriol 162:463-467

Shillito RD, Saul MW, Paszkowski J, Müller M, Potrykus I (1985) High efficiency direct gene transfer to plants. Biotechnol 3:1099-1103

Shivarova N, Förster W, Jacob H-E, Grigorova R (1983) Microbiological implications of electric field effects VII. Stimulation of plamid transformation of Bacillus cereus protoplasts by electric field pulses. Z Allg Mikrobiol 23:595-599

Somkuti GA, Steinberg DH (1987) Genetic transformation of Streptococcus thermophilus by electroporation. In: Neijssel OM, Van der Meer RR, Luyben KCHAM (eds) Proc 4th Eur Congr Biotechnol, Vol 1, Elsevier, Amsterdam, p 412

Sugar IP, Förster W, Neumann E (1987) Model of cell electrofusion, membrane electroporation, pore coalescence and percolation. Biophys Chem 26:321-335

Taketo A (1988) DNA transfection of Escherichia coli by electroporation BBA 949:318-324

Teissie J, Rols MP (1986) Fusion of mammalian cells in culture is obtained by creating the contact between cells after their electropermeabilization. Biochem Biophys Res Commun 140:258-266

Thierbach G, Schwarzer A, Pühler A (1988) Transformation of spheroplasts and protoplasts of Corynebacterium glutamicum. Appl Microbiol Biotechnol 29:356-362

Yoshihama M, Higashiro K, Rao EA, Akedo M, Shanabruch WG, Follettie MT, Walker GC, Sinskey AJ (1985) Cloning vector system for Corynebacterium glutamicum. J Bacteriol $162: 591-597$

Received July 5, 1988/Accepted September 14, 1988 